\title{
How many -amylase GH families are there in the CAZy database?
}

\author{
Janeek, Štefan; Svensson, Birte
}

Published in:

Amylase

Link to article, DOI:

10.1515/amylase-2022-0001

Publication date:

2022

Document Version

Publisher's PDF, also known as Version of record

Link back to DTU Orbit

Citation (APA):

Janeek, S., \& Svensson, B. (2022). How many -amylase GH families are there in the CAZy database? Amylase, 6, 1-10. https://doi.org/10.1515/amylase-2022-0001

\section{General rights}

Copyright and moral rights for the publications made accessible in the public portal are retained by the authors and/or other copyright owners and it is a condition of accessing publications that users recognise and abide by the legal requirements associated with these rights.

- Users may download and print one copy of any publication from the public portal for the purpose of private study or research.

- You may not further distribute the material or use it for any profit-making activity or commercial gain

- You may freely distribute the URL identifying the publication in the public portal

If you believe that this document breaches copyright please contact us providing details, and we will remove access to the work immediately and investigate your claim 


\section{Opinion}

Štefan Janeček*, Birte Svensson

\section{How many $\alpha$-amylase $\mathrm{GH}$ families are there in the CAZy database?}

https://doi.org/10.1515/amylase-2022-0001

Received November 15, 2021; accepted January 3, 2022.

\begin{abstract}
The CAZy database is a web-server for sequencebased classification of carbohydrate-active enzymes that has become the worldwide and indispensable tool for scientists engaged in this research field. It was originally created in 1991 as a classification of glycoside hydrolases (GH) and currently, this section of CAZy represents its largest part counting $172 \mathrm{GH}$ families. The present Opinion paper is devoted to the specificity of $\alpha$-amylase (EC 3.2.1.1) and its occurrence in the CAZy database. Among the 172 defined GH families, four, i.e. GH13, GH57, GH119 and GH126, may be considered as the $\alpha$-amylase GH families. This view reflects a historical background and traditions widely accepted during the previous decades with respect to the chronology of creating the individual GH families. It obeys the phenomenon that some amylolytic enzymes, which were used to create the individual GH families and were originally known as $\alpha$-amylases, according to current knowledge from later, more detailed characterization, need not necessarily represent genuine $\alpha$-amylases. Our Opinion paper was therefore written in an effort to invite the scientific community to think about that with a mind open to changes and to consider the seemingly unambiguous question in the title as one that may not have a simple answer.
\end{abstract}

Keywords: $\alpha$-amylase; GH families; CAZy database; sequence-different $\alpha$-amylases; dual enzyme specificities.

*Corresponding author: Štefan Janeček, Laboratory of Protein Evolution, Institute of Molecular Biology, Slovak Academy of Sciences, Dúbravská cesta 21, SK-84551 Bratislava, Slovakia; Department of Biology, Faculty of Natural Sciences, University of SS. Cyril and Methodius, Nám. J. Herdu 2, SK-91701 Trnava, Slovakia, E-mail: Stefan.Janecek@savba.sk

Birte Svensson, Enzyme and Protein Chemistry, Department of Biotechnology and Biomedicine, The Technical University of Denmark, Søltofts Plads, building 224, DK-2800 Kgs. Lyngby, Denmark

\section{Abbreviations}

CAZy, Carbohydrate-Active enZymes; CBM, carbohydratebinding module; CSR, conserved sequence region; $\mathrm{GH}$, glycoside hydrolase, SBD, starch binding domain.

\section{Introduction}

The current CAZy database (http://www.cazy.org/) that primarily catalogues structurally related catalytic domains of Carbohydrate-Active enZymes (CAZymes) [1] has its origin in the brilliant idea of Bernard Henrissat, who in 1991 classified glycoside hydrolases (GH) into families based on amino acid sequence similarities [2]. The overall classification concept most probably originated from classifying cellulases into families revealed by hydrophobic cluster analysis of their sequences [3]; an approach that has also been applied to $\alpha$-amylases [4]. Currently (November 2021), there are $172 \mathrm{GH}$ families and the entire CAZy database, in addition to GH classification, covers sections devoted to glycosyltransferases (GT; 114 families), polysaccharide lyases (PL; 42 families), carbohydrate esterases (CE; 19 families) and auxiliary activities (AA; 17 families); a section devoted to fully sequenced and annotated genomes is also a part of the database [2,5-10]. Due to $\sim 10 \%$ of CAZymes being multimodular [11,12], an independent classification is included of carbohydrate-binding modules (CBM; 88 families) [1,13]. The unmatched scope and impact of the CAZy database motivated a Wikipedia-like project entitled "CAZypedia" (http://www.cazypedia.org/), which was initiated over a decade ago [14] as an original source for documentary presentation of key information on individual families that is truly complementary to CAZy.

$\alpha$-Amylase (EC 3.2.1.1) is one of the enzymes attracting profound research interests, especially from the beginning of the 1990s at which time ideas to define a family around the $\alpha$-amylase became evident. Thus, based on both experimental [15-19] and in silico studies [20-24], the so-called $\alpha$-amylase enzyme family was established. By the 
opinion of the research community engaged in this field, this family in fact became synonymous with family GH13 of the CAZy database [2,25-29]. It was from the start in 1991 already clear that family GH13 was large and polyspecific, as compared to, e.g. families GH14 ( $\beta$-amylases) and GH15 (glucoamylases) [2]. Later GH15 attained additional enzyme specificities too [1]. Currently, the family GH13 ranks among the largest $\mathrm{GH}$ families [1]. The update of the GH classification in 1996 delivered a second $\alpha$-amylase family, namely GH57 [6]. According to the CAZy database today [1], the $\alpha$-amylase specificity might be present also in families GH119 and GH126 [30] (details will be explained below). It is worth mentioning that with regard to $\alpha$-amylase containing GH families, 15 of the $88 \mathrm{CBM}$ families in CAZy are so-called starch-binding domains (SBD) and/or glycogen-binding domains, which occur in multi-domain enzymes from the four GH families [31].

This Opinion paper offers the authors' views on the $\alpha$-amylase enzyme specificity and the corresponding four GH families as found in the CAZy database [1]. It is not the intention to comprehensively cover all relevant details as would be the case of a typical Review; and only selected key references are included.

\section{The main $\alpha$-amylase family GH13}

The main $\alpha$-amylase family is embodied by family GH13 as well-established during the past few decades $[1,25-30]$ and now widely accepted in the scientific community. The GH13 family is huge and counts (November 2021) more than 124,300 sequences from all three domains of life covering more than 30 different enzyme specificities (Table 1) [1,30]. At the higher hierarchical level, CAZy has implemented clans comprising more than one GH family and GH13 belongs to the clan GH-H together with families GH70 and GH77 [32-35]. Both of the latter families contain enzymes (Table 1) which possess fair hydrolytic side activities toward starch [36-45]. At a lower hierarchical level, GH13 has been divided into subfamilies [46]. Currently, CAZy lists 44 curator-approved GH13 subfamilies [1], and more are awaited soon [46-49]. Notably, before this official division of family GH13 into subfamilies in 2006 [46], two other subfamilies had been established of oligo-1,6-glucosidases and neopullulanases, based on specific differences in conserved sequence regions (CSR) [50]. Each of these two old subfamilies, in fact covers several enzyme specificities and official CAZy GH13 subfamilies [51-53].

Basic characteristics of family $\mathrm{GH} 13$ - and in a wider sense of clan GH-H - can be summarized as follows $[28,30,32,35,39,54-63]$ : (i) employing a retaining reaction mechanism; (ii) adopting a $(\beta / \alpha)_{8}$-barrel (i.e. the so-called TIM-barrel) fold for the catalytic domain; (iii) possessing a catalytic triad of an aspartic acid (nucleophile), a glutamic acid (proton donor) and an aspartic acid (transition-state stabilizer) situated at or near the C-termini of TIM-barrel strands $\beta 4, \beta 5$ and $\beta 7$, respectively; and (iv) sharing 4-7 CSRs in their amino acid sequences. The GH70 was established [1] as a family whose members contain a circularly permuted catalytic TIM-barrel domain compared to that of the main $\alpha$-amylase family GH13 [64]. However, it is of note that a group inside the GH70 - represented by 4,6- $\alpha$-glucanotransferases GtfC - was confirmed to have the TIM-barrel without circular permutation [65].

With regard to the individual GH13 subfamilies, some have been established and known for a long time to group typical fungal (GH13_1), bacterial liquefying (GH13_5), plant (GH13_6), archaeal (GH13_7), insect (GH13_15), animal (GH13_24), bacterial saccharifying (GH13_28) and actinobacterial (GH13_32) $\alpha$-amylases [46,66-69]. Currently, most of these above-mentioned and originally taxonomically pure subfamilies, also contain other taxa [35]. For example, some bacterial $\alpha$-amylases have already been characterized from GH13_6 (originally only plant sources) and from GH13_7 (originally only archaeal sources), i.e. $\alpha$-amylase from Massilia timonae in the GH13_6 [70], whereas the counterpart from Sinomicrobium sp. 5DNS001 in GH13_7 [71]. Moreover, an additional archaeal $\alpha$-amylase subfamily GH13_43 was recently established for $\alpha$-amylases from haloarchaeons [72]; subfamily GH13_7 thus obviously being reserved for $\alpha$-amylases from hyperthermophilic archaeal thermococci $[1,67]$. With regard to, for example, fungal $\alpha$-amylases, these were originally placed in the subfamily GH13_1 with Taka-amylase A from Aspergillus oryzae as the main representative [54], but $\alpha$-amylases from fungi were later found in other subfamilies, such as GH13_5 [73], GH13_32 [74] and GH13_42 [75,76].

In addition to the GH13 subfamilies mentioned above having $\alpha$-amylase specificity, subfamily GH13_36 contains $\alpha$-amylases with an expanded enzyme specificity towards pullulan and cyclodextrins and can hydrolyse both $\alpha-1,4$ and $\alpha-1,6$-linkages [52]. Notably, this subfamily was originally recognised as intermediate to the so-called oligo-1,6glucosidase and neopullulanase subfamilies [50]. Moreover, the $\alpha$-amylase family GH13 contains some non-enzymatic transport proteins, $\mathrm{rBAT}$ and $4 \mathrm{~F} 2 \mathrm{hc}$ [77-81], recently suggested to represent "fake" or orphan $\alpha$-glucosidases [82]. These proteins, typically found in mammals (or higher Metazoans), in most cases lost either completely or in part the GH13 catalytic residues, but still exhibited an unambiguous sequence homology in CSRs outside the regions bearing the GH13 catalytic machinery [35]. 
Table 1: Specificities in the $\alpha$-amylase GH families. ${ }^{a}$

\begin{tabular}{|c|c|c|c|c|c|}
\hline Family & Enzyme & EC No. & Family & Enzyme & EC No. \\
\hline \multirow[t]{30}{*}{ GH13 } & $\alpha$-Amylase & 3.2.1.1 & & Sucrose-6(F)-phosphate & 2.4.1.329 \\
\hline & Oligo-1,6-glucosidase & 3.2.1.10 & & phosphorylase & \\
\hline & $\alpha$-Glucosidase & 3.2 .1 .20 & & Glucosylglycerate phosphorylase & 2.4.1.352 \\
\hline & Pullulanase & 3.2 .1 .41 & & Glucosylglycerol phosphorylase & 2.4.1.359 \\
\hline & Amylopullulanase & $3.2 .1 .1 / 41$ & & $\begin{array}{l}\alpha-1,4 \text {-Glucan: phosphate } \\
\alpha \text {-maltosyltransferase }\end{array}$ & 2.4.99.16 \\
\hline & Sucrose $\alpha$-glucosidase & 3.2.1.48 & & Isomaltulose synthase & 5.4.99.11 \\
\hline & Cyclomaltodextrinase & 3.2 .1 .54 & & Maltooligosyltrehalose synthase & 5.4.99.15 \\
\hline & Maltotetraose-forming amylase & 3.2 .1 .60 & & Trehalose synthase & 5.4 .99 .16 \\
\hline & Isoamylase & 3.2.1.68 & & hc-rBAT protein & - \\
\hline & Dextran glucosidase & 3.2 .1 .70 & & 4F2hc antigen & - \\
\hline & Trehalose 6-phosphate hydrolase & 3.2.1.93 & $\mathrm{GH} 70$ & Dextransucrase & 2.4.1.5 \\
\hline & Maltohexaose-forming amylase & 3.2.1.98 & & Alternansucrase & 2.4.1.140 \\
\hline & Maltotriose-forming amylase & 3.2.1.116 & & $\alpha-1,3$-Branching glucansucrase & 2.4 .1 .362 \\
\hline & Maltogenic amylase & 3.2.1.133 & & Mutansucrase & 2.4.1.372 \\
\hline & Neopullulanase & 3.2.1.135 & & $\alpha-1,6 / \alpha-1,2-$-Branching & 2.4.1.373 \\
\hline & Maltooligosyltrehalose & 3.2.1.141 & & glucansucrase & \\
\hline & trehalohydrolase & & & Reuteransucrase & 2.4.1.- \\
\hline & Maltopentaose-forming amylase & 3.2.1.- & & 4,3- $\alpha$-Glucanotransferase & 2.4.1.- \\
\hline & Sucrose hydrolase & 3.2.1.- & & 4,6- $\alpha$-Glucanotransferase & 2.4.1.- \\
\hline & $\begin{array}{l}\text { Cyclic } \alpha \text {-maltosyl-1,6-maltose } \\
\text { hydrolase }\end{array}$ & 3.2.1.- & GH77 & $\begin{array}{l}\text { 4- } \alpha \text {-Glucanotransferase } \\
\text { (amylomaltase) }\end{array}$ & 2.4.1.25 \\
\hline & Amylosucrase & 2.4.1.4 & GH57 & $\alpha$-Amylase & 3.2.1.1 \\
\hline & Sucrose phosphorylase & 2.4.1.7 & & Maltogenic amylase & 3.2.1.133 \\
\hline & Glucan branching enzyme & 2.4.1.18 & & Amylopullulanase & 3.2.1.1/41 \\
\hline & Cyclodextrin glucanotransferase & 2.4.1.19 & & Cyclomaltodextrinase & 3.2 .1 .54 \\
\hline & 4- $\alpha$-Glucanotransferase & 2.4.1.25 & & $\alpha$-Galactosidase & 3.2.1.22 \\
\hline & Glucan debranching enzyme & 2.4.1.25/3.2.1.33 & & Non-specified amylase & 3.2.1.- \\
\hline & $\begin{array}{l}\text { Oligosaccharide } \alpha \text {-4- } \\
\text { glucosyltransferase }\end{array}$ & 2.4.1.161 & & Glucan branching enzyme & 2.4.1.18 \\
\hline & $\alpha-1,3-$ Glucan synthase & 2.4.1.183 & & 4- $\alpha$-Glucanotransferase & 2.4.1.25 \\
\hline & Isocyclomaltooligosaccharide & 2.4.1.248 & GH119 & $\alpha$-Amylase & 3.2.1.1 \\
\hline & glucanotransferase & & GH126 & $\alpha$-Amylase & 3.2.1.1 \\
\hline
\end{tabular}

${ }^{a}$ Details concerning the individual enzymes can be found in text. The 4- $\alpha$-glucanotransferase from the family GH77 is known also as amylomaltase and disproportionating enzyme.

The $\alpha$-amylase family GH13 consists mainly of enzymes from three enzyme classes: (i) hydrolases (EC 3); (ii) transferases (EC 2); and (iii) isomerases (EC 5). Perhaps, the most intriguing observations in recent years were a group of amylolytic enzymes represented by the experimentally characterized, but, until now, still insufficiently specified "amylase" BmaN1 from Bacillus megaterium [49]. It is closely related to $\alpha$-amylases represented by the $\alpha$-amylase 
BaqA from Bacillus aquimaris [47,48], but by comparing with the group defined by $\alpha$-amylase BaqA, it may possess an aberrant catalytic machinery [49].

\section{The second $\alpha$-amylase family - GH57}

The family GH57 was established in 1996 by the second published update of the GH classification [6]. The main reason for creating this family was two presumed $\alpha$-amylases - one from the bacterium Dictyoglomus thermophilum [83] and the other from the archaeon Pyrococcus furiosus [84]. Their amino acid sequences were obviously different from those already classified in family GH13 [30], although efforts to reveal sequence features joining GH13 and GH57 persisted at the time, mainly owing to the lack of structural data [85]. The sequence-structural independence of family GH57 from the main $\alpha$-amylase family GH13 was definitively settled by the first solved GH57 three-dimensional structure of 4- $\alpha$-glucanotransferase from Thermococcus litoralis [86], identification of its catalytic nucleophile [87] as well as of the entire catalytic machinery in the related Thermococcus hydrothermalis amylopullulanase [88]. CSRs typical for family GH57 were established by the latter study [88].

Family GH57 could be characterized by the following criteria [30,86-92]: (i) employing a retaining reaction mechanism; (ii) adopting a $(\beta / \alpha)_{7}$-barrel catalytic domain fold, a so-called incomplete TIM-barrel, including a bundle of a few $\alpha$-helices succeeding the barrel; (iii) having catalytic machinery consisting of a glutamic acid (nucleophile) and an aspartic acid (proton donor) situated at or near the $C$-termini of $(\beta / \alpha)_{7}$-barrel strands $\beta 4$ and $\beta 7$, respectively; and (iv) sharing 5 CSRs in their amino acid sequences.

This family, like the main $\alpha$-amylase family GH13, is polyspecific, although the number of different specificities is less than 10 compared to the more than 30 found in GH13 [1,30] (Table1). Currently (November 2021), family GH57 has almost 4,000 sequences from prokaryotes, roughly divided 3:1 between Bacteria and Archaea [1]. However, it is worth remarking that the two founding family members are in fact 4- $\alpha$-glucanotransferases $[93,94]$, but were originally supposed to be $\alpha$-amylases from $D$. thermophilum [83] and $P$. furiosus [84]. Moreover, yet another member that may be crucial for naming family GH57 as " $\alpha$-amylase" family is the $\alpha$-amylase from Methanocaldococcus jannaschii [85], which is an amylopullulanase and not a strict $\alpha$-amylase as it showed $>80 \%$ activity on pullulan compared to on soluble starch [95]. Nevertheless, the family GH57 has become well-known as the second $\alpha$-amylase family $[30,92]$.

Family GH57 contains a few examples of so-called dual enzyme specificities. Thus the $\alpha$-amylase from Thermotoga maritima showed also $\alpha$-glucan branching [89,96-99] and the amylopullulanase from Staphylothermus marinus had also cyclomaltodextrinase specificity [100]. Finally, for some specificities, namely of $\alpha$-amylase, $\alpha$-glucan branching enzyme and 4- $\alpha$-glucanotransferase, GH57 members referred to as so-called enzyme-like proteins were revealed to have either incomplete or to fully lack catalytic machinery $[101,102]$. Until now, no experimental evidence has demonstrated the eventual activity/ specificity of the corresponding proteins.

\section{The family GH119}

The eventual third $\alpha$-amylase family in CAZy GH119 was established in 2006 based on the report on $\alpha$-amylase IgtZ from Bacillus circulans [103]. This prokaryotic family having only 38 bacterial members (November 2021) is one of the smallest GH families in CAZy [1]. $\alpha$-Amylase IgtZ is still the only experimentally characterized GH119 member and has been shown to act on maltotetraose, larger maltooligosaccharides, amylose and soluble starch, producing glucose and maltooligosaccharides up to maltopentaose [103]. In addition to the catalytic domain, the IgtZ sequence includes three SBDs - two of family CBM25 and one CBM20 [31,103] - as well as at least one fibronectin type III domain [29], that quite frequently occurs with various $\mathrm{GH}$ families and is also in other CAZy sections of GTs, PLs, CEs and AAs [104].

It should be pointed out that there is still a serious lack of information concerning the catalytic domain fold and machinery of GH119 [30]. A retaining reaction mechanism was confirmed by polarimetric analysis of the anomeric configuration of maltooligosaccharides released by $\alpha$-amylase IgtZ from maltopentaosyl trehalose [103]. Trehalose was even the major hydrolysis product in reactions on higher maltooligosyl trehaloses [103] suggesting the substrate specificity of $\alpha$-amylase IgtZ as maltooligosyl trehalose trehalohydrolase [105]. This behaviour may indicate that $B$. circulans $\alpha$-amylase as the founding family GH119 member does not necessarily have strict $\alpha$-amylase specificity.

In fact, the only source of structural knowledge on GH119 until now is an in silico study from 2012 [106] that predicted the catalytic domain fold as an incomplete TIMbarrel closely related to that of family GH57 and a highly 
convincing prediction of five CSRs and catalytic machinery shared with family GH57. However, without experimental evidence of a solved three-dimensional structure and functional characterization of mutants of the two putative catalytic residues, it is not possible to consolidate the proposed close relationship of the two families [30].

\section{The family GH126}

The fourth GH family to be considered as $\alpha$-amylase family, is family GH126, established in 2011 based on a paper describing the three-dimensional structure of the CPF_2247 protein from the Clostridium perfringens genome [107]. The structure adopts an $(\alpha / \alpha)_{6}$-barrel fold and thus differs from the classical and incomplete TIM-barrels, respectively, in families GH13 and GH57 [29,30,54,86]. The $(\alpha / \alpha)_{6}$-barrel fold is well-known, e.g. from family GH15 of glucoamylases [108-110]. With regard to family GH126, it is of a special interest from both a sequence and threedimensional structure point of view where it resembles $\beta$-glucan-active enzymes from families GH8 and GH48, constituting clan GH-M [90]. These $\beta$-glucosidases employ an inverting reaction mechanism [111,112] and it seems rather strange that the similar GH126 amylolytic enzyme CPF_2247 would be an $\alpha$-amylase that by definition is a retaining enzyme [28]. Although the catalytic machinery was not determined in family GH126 as no ligand was seen in the crystal structure of the CPF_2247 protein [107], both catalytic residues of members in clan GH-M, a glutamic acid and an aspartic acid playing the roles of the general acid and general base, respectively [111,112], have counterparts in GH126 [107].

Based on biochemical analyses [107], it is beyond doubt that the protein CPF_2247 is an $\alpha$-glucanase and the remaining uncertainty is whether or not it represents a true $\alpha$-amylase [30]. The enzyme exhibited activity towards amylose and glycogen (but neither on pullulan nor for that sake on cellulose) and produced maltooligosaccharides from maltose through maltoheptaose, whereas it released glucose from maltooligosaccharides, maltopentose being the minimal substrate [107]. This means that the former activity agrees with being $\alpha$-amylase-like and endo-acting, while the latter may represent an exo-mode of action similar to $\alpha$-glucosidases [30].

It is of note that a three-dimensional structure has been determined of one more family GH126 member, PssZ from Listeria monocytogenes [113], which was found to be a glycosidase specific to a biofilm matrix exopolysaccharide consisting of $N$-acetylmannosamine and galactose in a 2:1 ratio [114].
Currently (November 2021), family GH126 counts more than 1,300 bacterial members [1]. Although the first actinobacterial sequence (from a Brevibacterium genus) was recently classified in this family [1], from its creation, GH126 was known as prokaryotic with members solely originating from the phylum Firmicutes [115]. However, a recent in silico study, aimed to disclose potential GH126 members outside of Firmicutes, convincingly identified 17 bacterial proteins from several other phyla (Proteobacteria, Actinobacteria and Bacteroidetes), hence expanding the taxonomic occurrence [116]. Seven CSRs were proposed for family GH126, along with elucidating evolutionary relationships within the family [115]. Additionally, based on structural comparison of both the CPF_2247 $\alpha$-amylase and the PssZ protein with representatives of other $\mathrm{GH}$ families containing $(\alpha / \alpha)_{6}$-barrel catalytic domains, an evolutionary relationship was proposed of GH126 with family GH76 [115]. This included sharing one of the two catalytic residues of the $B$. circulans GH76 $\alpha$-mannanase [117] that is an $\alpha$-glycan-active enzyme employing a retaining reaction mechanism [1].

\section{Conclusions}

The question from the title of this Opinion paper "How many $\alpha$-amylase $\mathrm{GH}$ families are there in the CAZy database?" - has a very simple answer namely that there are four $\mathrm{GH} \alpha$-amylase families, GH13, GH57, GH119 and GH126, in CAZy. However, in the light of its background history, traditions that may persist even in science and especially the genuine scientific knowledge achieved until now, this seemingly clear answer may be a bit more complicated or at least ambiguous. The true $\alpha$-amylase enzyme specificity - represented by for example Taka-amylase A from Aspergillus oryzae - may strictly speaking be found only in family GH13, since for the three remaining families GH57, GH119 and GH126 conclusive proof of the presence of this $\alpha$-amylase specificity among their members still lags behind. Thus for family GH57, the two original " $\alpha$-amylase" members from Dictyoglomus thermophilum and Pyrococcus furiosus are 4- $\alpha$-glucanotransferases, whereas the third " $\alpha$-amylase" from Methanocaldococcus jannaschi seems to be an amylopullulanase. With regard to family GH119, its central member, the " $\alpha$-amylase" from Bacillus circulans, exhibited also specificity as a maltooligosyl trehalose trehalohydrolase. Finally, for the Clostridium perfringens " $\alpha$-amylase" - the founding member of family GH126 doubts still exist about its endo-versus exo-mode of action as well as if this amylolytic enzyme employs a retaining 
or an inverting reaction mechanism. Therefore, the aim of this article is not to provide the reader with a dogmatic unchangeable learning, but to offer an open view based on what we know so far and permit the $\alpha$-amylase-positive scientific community to see the full complexity of this exciting issue.

Acknowledgments: This work was financially supported by the Grant No. 2/0146/21 from the Slovak Grant Agency VEGA (SJ) and Grant No. 6108-00476B from Independent Research Fund Denmark (BS).

Conflict of interest: The authors declare no conflict of interest.

\section{References}

[1] Lombard V., Golaconda Ramulu H., Drula E., Coutinho P.M., Henrissat B., The carbohydrate-active enzymes database (CAZy) in 2013. Nucleic Acids Res. 2014, 42, D490-D495. https://doi.org/10.1093/nar/gkt1178

[2] Henrissat B., A classification of glycosyl hydrolases based on amino acid sequence similarities. Biochem. J. 1991, 280, 309-316. https://doi.org/10.1042/bj2800309

[3] Henrissat B., Claeyssens M., Tomme P., Lemesle L., Mornon J.P., Cellulase families revealed by hydrophobic cluster analysis. Gene 1989, 81, 83-95. https://doi. org/10.1016/0378-1119(89)90339-9

[4] Raimbaud E., Buleon A., Perez S., Henrissat B., Hydrophobic cluster analysis of the primary sequences of $\alpha$-amylases. Int. J. Biol. Macromol. 1989, 11, 217-225. https://doi. org/10.1016/0141-8130(89)90072-x

[5] Henrissat B., Bairoch A., New families in the classification of glycosyl hydrolases based on amino acid sequence similarities. Biochem. J. 1993, 293, 781-788. https://doi. org/10.1042/bj2930781

[6] Henrissat B., Bairoch A., Updating the sequence-based classification of glycosyl hydrolases. Biochem. J. 1996, 316, 695-696. https://doi.org/10.1042/bj3160695

[7] Campbell J.A., Davies G.J., Bulone V., Henrissat B., A classification of nucleotide-diphospho-sugar glycosyltransferases based on amino acid sequence similarities. Biochem. J. 1997, 326, 929-939. https://doi. org/10.1042/bj3260929u

[8] Coutinho P.M., Deleury E., Davies G.J., Henrissat B., An evolving hierarchical family classification for glycosyltransferases. J. Mol. Biol. 2003, 328, 307-317. https:// doi.org/10.1016/s0022-2836(03)00307-3

[9] Lombard V., Bernard T., Rancurel C., Brumer H., Coutinho P.M., Henrissat B., A hierarchical classification of polysaccharide lyases for glycogenomics. Biochem. J. 2010, 432, 437-444. https://doi.org/10.1042/BJ20101185

[10] Levasseur A., Drula E., Lombard V., Coutinho P.M., Henrissat B., Expansion of the enzymatic repertoire of the CAZy database to integrate auxiliary redox enzymes. Biotechnol. Biofuels 2013, 6, 41. https://doi.org/10.1186/1754-6834-6-41

[11] Janecek S., Sevcik J., The evolution of starch-binding domain. FEBS Lett. 1999, 456, 119-125. https://doi.org/10.1016/s00145793(99)00919-9

[12] Cockburn D., Wilkens C., Ruzanski C., Andersen S., Nielsen J.W., Smith A., Field R., Willemoës M., Abou Hachem M., Svensson B., Analysis of surface binding sites (SBSs) in carbohydrate active enzymes with focus on glycoside hydrolase families 13 and 77 - a mini-review. Biologia 2014, 69, 705-712. https://doi.org/10.2478/s11756-014-0373-9

[13] Boraston A.B., Bolam D.N., Gilbert H.J., Davies G.J., Carbohydrate-binding modules: fine-tuning polysaccharide recognition. Biochem. J. 2004, 382, 769-781. https://doi. org/10.1042/BJ20040892

[14] CAZypedia Consortium, Ten years of CAZypedia: a living encyclopedia of carbohydrate-active enzymes. Glycobiology 2018, 28, 3-8. https://doi.org/10.1093/glycob/cwx089

[15] Amemura A., Chakraborty R., Fujita M., Noumi T., Futai M., Cloning and nucleotide sequence of the isoamylase gene from Pseudomonas amyloderamosa SB-15. J. Biol. Chem. 1988, 263, 9271-9275. https://doi.org/10.1016/S0021-9258(19)76535-1

[16] Kuriki T., Imanaka T., Nucleotide sequence of the neopullulanase gene from Bacillus stearothermophilus. J. Gen. Microbiol. 1989, 135, 1521-1528. https://doi. org/10.1099/00221287-135-6-1521

[17] Watanabe K., Kitamura K., Iha H., Suzuki Y., Primary structure of the oligo-1,6-glucosidase of Bacillus cereus ATCC7064 deduced from the nucleotide sequence of the cloned gene. Eur. J. Biochem. 1990, 192, 609-620. https://doi. org/10.1111/j.1432-1033.1990.tb19267.x

[18] Nakamura A., Haga K., Ogawa S., Kuwano K., Kimura K., Yamane K., Functional relationships between cyclodextrin glucanotransferase from an alkalophilic Bacillus and $\alpha$-amylases. Site-directed mutagenesis of the conserved two Asp and one Glu residues. FEBS Lett. 1992, 296, 37-40. https://doi.org/10.1016/0014-5793(92)80398-z

[19] Takata H., Kuriki T., Okada S., Takesada Y., lizuka M., Minamiura N., Imanaka T., Action of neopullulanase. Neopullulanase catalyzes both hydrolysis and transglycosylation at $\alpha$-(1à4)- and $\alpha$-(1à6)-glucosidic linkages. J. Biol. Chem. 1992, 267, 18447-18452. https://doi. org/10.1016/S0021-9258(19)36983-2

[20] MacGregor E.A., $\alpha$-Amylase structure and activity. J. Protein Chem. 1988, 7, 399-415. https://doi.org/10.1007/ BF01024888

[21] Svensson B., Regional distant sequence homology between amylases, $\alpha$-glucosidases and transglucanosylases. FEBS Lett. 1988, 230, 72-6. https://doi.org/10.1016/00145793(88)80644-6

[22] MacGregor E.A., Svensson B., A super-secondary structure predicted to be common to several $\alpha$-1,4-d-glucan-cleaving enzymes. Biochem. J. 1989, 259, 145-152. https://doi. org/10.1042/bj2590145

[23] Jespersen H.M., MacGregor E.A., Sierks M.R., Svensson B., Comparison of the domain-level organization of starch hydrolases and related enzymes. Biochem. J. 1991, 280, 51-55. https://doi.org/10.1042/bj2800051

[24] Jespersen H.M., MacGregor E.A., Henrissat B., Sierks M.R., Svensson B., Starch- and glycogen-debranching and 
branching enzymes: prediction of structural features of the catalytic $(\beta / \alpha)_{8}$-barrel domain and evolutionary relationship to other amylolytic enzymes. J. Protein Chem. 1993, 12, 791-805. https://doi.org/10.1007/BF01024938

[25] MacGregor E.A., Relationships between structure and activity in the $\alpha$-amylase family of starch-metabolising enzymes. Starch 1993, 45, 232-237. https://doi.org/10.1002/ star.19930450705

[26] Janecek S., Parallel $\beta / \alpha$-barrels of $\alpha$-amylase, cyclodextrin glycosyltransferase and oligo-1,6-glucosidase versus the barrel of $\beta$-amylase: evolutionary distance is a reflection of unrelated sequences. FEBS Lett. 1994, 353, 119-123. https:// doi.org/10.1016/0014-5793(94)01019-6

[27] Svensson B., Protein engineering in the $\alpha$-amylase family: catalytic mechanism, substrate specificity, and stability. Plant Mol. Biol. 1994, 25, 141-157. https://doi.org/10.1007/ BF00023233

[28] Kuriki T., Imanaka T., The concept of the $\alpha$-amylase family: structural similarity and common catalytic mechanism. J. Biosci. Bioeng. 1999, 87, 557-565. https://doi.org/10.1016/ s1389-1723(99)80114-5

[29] Uitdehaag J.C., Mosi R., Kalk K.H., van der Veen B.A., Dijkhuizen L., Withers S.G., Dijkstra B.W., X-ray structures along the reaction pathway of cyclodextrin glycosyltransferase elucidate catalysis in the $\alpha$-amylase family. Nat. Struct. Biol. 1999, 6, 432-436. https://doi.org/10.1038/8235

[30] Janecek S., Svensson B., MacGregor E.A., $\alpha$-Amylase: an enzyme specificity found in various families of glycoside hydrolases. Cell. Mol. Life Sci. 2014, 71, 1149-1170. https:// doi.org/10.1007/s00018-013-1388-z

[31] Janecek S., Marecek F., MacGregor E.A., Svensson B., Starchbinding domains as CBM families - history, occurrence, structure, function and evolution. Biotechnol. Adv. 2019, 37, 107451. https://doi.org/10.1016/j.biotechadv.2019.107451

[32] MacGregor E.A., Janecek S., Svensson B., Relationship of sequence and structure to specificity in the $\alpha$-amylase family of enzymes. Biochim. Biophys. Acta 2001, 1546, 1-20. https:// doi.org/10.1016/s0167-4838(00)00302-2

[33] Moulis C., Andre I., Remaud-Simeon M., GH13 amylosucrases and $\mathrm{GH} 70$ branching sucrases, atypical enzymes in their respective families. Cell. Mol. Life Sci. 2016, 73, 2661-2679. https://doi.org/10.1007/s00018-016-2244-8

[34] Meng X., Gangoiti J., Bai Y., Pijning T., Van Leeuwen S.S., Dijkhuizen L., Structure-function relationships of family GH70 glucansucrase and 4,6- $\alpha$-glucanotransferase enzymes, and their evolutionary relationships with family GH13 enzymes. Cell. Mol. Life Sci. 2016, 73, 2681-2706. https://doi. org/10.1007/s00018-016-2245-7

[35] Janecek S., Gabrisko M., Remarkable evolutionary relatedness among the enzymes and proteins from the $\alpha$-amylase family. Cell. Mol. Life Sci. 2016, 73, 2707-2725. https://doi. org/10.1007/s00018-016-2246-6

[36] Leemhuis H., Dijkman W.P., Dobruchowska J.M., Pijning T., Grijpstra P., Kralj S., Kamerling J.P., Dijkhuizen L., 4,6- $\alpha$-Glucanotransferase activity occurs more widespread in Lactobacillus strains and constitutes a separate GH70 subfamily. Appl. Microbiol. Biotechnol. 2013, 97, 181-193. https://doi.org/10.1007/s00253-012-3943-1

[37] Xiang G., Buwalda P.L., van der Maarel M.J.E.C., Leemhuis H., The thermostable 4,6- $\alpha$-glucanotransferase of Bacillus coagulans DSM 1 synthesizes isomaltooligosaccharides. Amylase 2021, 5, 13-22. https://doi.org/10.1515/amylase2021-0002

[38] Gangoiti J., Pijning T., Dijkhuizen L., Biotechnological potential of novel glycoside hydrolase family 70 enzymes synthesizing $\alpha$-glucans from starch and sucrose. Biotechnol. Adv. 2018, 36, 196-207. https://doi.org/10.1016/j.biotechadv.2017.11.001

[39] Molina M., Cioci G., Moulis C., Severac E., Remaud-Simeon M., Bacterial $\alpha$-glucan and branching sucrases from $\mathrm{GH} 70$ family: discovery, structure-function relationship studies and engineering. Microorganisms 2021, 9, 1607. https://doi. org/10.3390/microorganisms 9081607

[40] Li X., Meng X., de Leeuw T.C., Te Poele E.M., Pijning T., Dijkhuizen L., Liu W., Enzymatic glucosylation of polyphenols using glucansucrases and branching sucrases of glycoside hydrolase family 70. Crit. Rev. Food Sci. Nutr. 2021, 15, 1-21. https://doi.org/10.1080/10408398.2021.2016598

[41] Przylas I., Tomoo K., Terada Y., Takaha T., Fujii K., Saenger W., Sträter N., Crystal structure of amylomaltase from Thermus aquaticus, a glycosyltransferase catalysing the production of large cyclic glucans. J. Mol. Biol. 2000, 296, 873-886. https:// doi.org/10.1006/jmbi.1999.3503

[42] Kaper T., Leemhuis H., Uitdehaag J.C., van der Veen B.A., Dijkstra B.W., van der Maarel M.J., Dijkhuizen L., Identification of acceptor substrate binding subsites +2 and +3 in the amylomaltase from Thermus thermophilus HB8. Biochemistry 2007, 46, 5261-5269. https://doi.org/10.1021/bi602408j

[43] Jung J.H., Jung T.Y., Seo D.H., Yoon S.M., Choi H.C., Park B.C., Park C.S., Woo E.J., Structural and functional analysis of substrate recognition by the 250 s loop in amylomaltase from Thermus brockianus. Proteins 2011, 79, 633-644. https://doi. org/10.1002/prot.22911

[44] Kuchtova A, Janecek S., In silico analysis of family GH77 with focus on amylomaltases from borreliae and disproportionating enzymes DPE2 from plants and bacteria. Biochim. Biophys. Acta 2015, 1854, 1260-1268. https://doi.org/10.1016/j. bbapap.2015.05.009

[45] Marecek F., Møller M.S., Svensson B., Janecek S., A putative novel starch-binding domain revealed by in silico analysis of the $\mathrm{N}$-terminal domain in bacterial amylomaltases from the family GH77. 3 Biotech 2021, 11, 229. https://doi.org/10.1007/ s13205-021-02787-8

[46] Stam M.R., Danchin E.G.J., Rancurel C., Coutinho P.M., Henrissat B., Dividing the large glycoside hydrolase family 13 into subfamilies: towards improved functional annotations of $\alpha$-amylase-related proteins. Protein Eng. Des. Sel. 2006, 19, 555-562. https://doi.org/10.1093/protein/gzl044

[47] Puspasari F., Radjasa O.K., Noer A.S., Nurachman Z., Syah Y.M., van der Maarel M., Dijkhuizen L., Janecek S., Natalia D., Raw starch-degrading $\alpha$-amylase from Bacillus aquimaris MKSC 6.2: isolation and expression of the gene, bioinformatics and biochemical characterization of the recombinant enzyme. J. Appl. Microbiol. 2013, 114, 108-120. https://doi.org/10.1111/jam.12025

[48] Janecek S., Kuchtova A., Petrovicova S., A novel GH13 subfamily of $\alpha$-amylases with a pair of tryptophans in the helix $\alpha 3$ of the catalytic TIM-barrel, the LPDlx signature in the conserved sequence region $\mathrm{V}$ and a conserved aromatic motif at the C-terminus. Biologia 2015, 70, 1284-1294. https://doi. org/10.1515/biolog-2015-0165 
[49] Sarian F.D., Janecek S., Pijning T., Ihsanawati, Nurachman Z., Radjasa O.K., Dijkhuizen L., Natalia D., van der Maarel M.J., A new group of glycoside hydrolase family $13 \alpha$-amylases with an aberrant catalytic triad. Sci. Rep. 2017, 7, 44230. https:// doi.org/10.1038/srep44230

[50] Oslancova A., Janecek S., Oligo-1,6-glucosidase and neopullulanase enzyme subfamilies from the $\alpha$-amylase family defined by the fifth conserved sequence region. Cell. Mol. Life Sci. 2002, 59, 1945-1959. https://doi.org/10.1007/ pl00012517

[51] Park K.H., Kim T.J., Cheong T.K., Kim J.W., Oh B.H., Svensson B., Structure, specificity and function of cyclomaltodextrinase, a multispecific enzyme of the $\alpha$-amylase family. Biochim. Biophys. Acta 2000, 1478, 165-185. https://doi.org/10.1016/ s0167-4838(00)00041-8

[52] Majzlova K., Pukajova Z., Janecek S., Tracing the evolution of the $\alpha$-amylase subfamily GH13_36 covering the amylolytic enzymes intermediate between oligo-1,6-glucosidases and neopullulanases. Carbohydr. Res. 2013, 367, 48-57. https:// doi.org/10.1016/j.carres.2012.11.022

[53] Kuchtova A., Janecek S., Domain evolution in enzymes of the neopullulanase subfamily. Microbiology 2016, 162, 20992115. https://doi.org/10.1099/mic.0.000390

[54] Matsuura Y., Kusunoki M., Harada W., Kakudo M., Structure and possible catalytic residues of Taka-amylase A. J. Biochem. 1984, 95, 697-702. https://doi.org/10.1093/oxfordjournals. jbchem.a134659

[55] Buisson G., Duee E., Haser R., Payan F., Three dimensional structure of porcine pancreatic $\alpha$-amylase at $2.9 \AA$ resolution. Role of calcium in structure and activity. EMBO J. 1987, 6, 3909-3916. https://doi.org/10.1002/j.1460-2075.1987. tb02731.x

[56] Kadziola A., Abe J., Svensson B., Haser R., Crystal and molecular structure of barley $\alpha$-amylase. J. Mol. Biol. 1994, 239, 104-121. https://doi.org/10.1006/jmbi.1994

[57] Vujicic-Zagar A., Pijning T., Kralj S., Lopez C.A., Eeuwema W., Dijkhuizen L., Dijkstra B.W., Crystal structure of a 117 $\mathrm{kDa}$ glucansucrase fragment provides insight into evolution and product specificity of GH70 enzymes. Proc. Natl. Acad. Sci. USA 2010, 107, 21406-21411. https://doi.org/10.1073/ pnas. 1007531107

[58] Svensson B., Tovborg Jensen M., Mori H., Bak-Jensen K.S., Bønsager B., Nielsen P.K., Kramhøft B., Prætorius-Ibba M., Nøhr J., Juge N., Greffe L., Williamson G., Driguez H., Fascinating facets of function and structure of amylolytic enzymes of glycoside hydrolase family 13. Biologia 2002, 57 (Suppl. 11), 5-19.

[59] Janecek S., How many conserved sequence regions are there in the $\alpha$-amylase family? Biologia 2002, 57 (Suppl. 11), 29-41.

[60] van der Maarel M.J., van der Veen B., Uitdehaag J.C., Leemhuis H., Dijkhuizen L., Properties and applications of starchconverting enzymes of the $\alpha$-amylase family. J. Biotechnol. 2002, 94, 137-155. https://doi.org/10.1016/s01681656(01)00407-2

[61] MacGregor E.A., An overview of clan GH-H and distantlyrelated families. Biologia 2005, 60 (Suppl. 16), 5-12.

[62] Møller M.S., Henriksen A., Svensson B., Structure and function of $\alpha$-glucan debranching enzymes. Cell. Mol. Life Sci. 2016, 73, 2619-2641. https://doi.org/10.1007/s00018-016-2241-y
[63] Bozic N., Loncar N., Slavic M.S., Vujcic Z., Raw starch degrading $\alpha$-amylases: an unsolved riddle. Amylase 2017, 1, 12-25. https://doi.org/10.1515/amylase-2017-0002

[64] MacGregor E.A., Jespersen H.M., Svensson B., A circularly permuted $\alpha$-amylase-type $\alpha / \beta$-barrel structure in glucansynthesizing glucosyltransferases. FEBS Lett. 1996, 378, 263-236. https://doi.org/10.1016/0014-5793(95)01428-4

[65] Gangoiti J., Pijning T., Dijkhuizen L., The Exiguobacterium sibiricum 255-15 GtfC enzyme represents a novel glycoside hydrolase 70 subfamily of 4,6- $\alpha$-glucanotransferase enzymes. Appl. Environ. Microbiol. 2015, 82, 756-766. https://doi. org/10.1128/AEM.03420-15

[66] Janecek S., Sequence similarities and evolutionary relationships of microbial, plant and animal $\alpha$-amylases. Eur. J. Biochem. 1994, 224, 519-524. https://doi.org/10.1111/j.14321033.1994.00519.x

[67] Janecek S., Leveque E., Belarbi A., Haye B., Close evolutionary relatedness of $\alpha$-amylases from Archaea and plants. J. Mol. Evol. 1999, 48, 421-426. https://doi.org/10.1007/ pl00006486

[68] Da Lage J.L., Feller G., Janecek S., Horizontal gene transfer from Eukarya to bacteria and domain shuffling: the $\alpha$-amylase model. Cell. Mol. Life Sci. 2004, 61, 97-109. https://doi. org/10.1007/s00018-003-3334-y

[69] Hostinova E., Janecek S., Gasperik J., Gene sequence, bioinformatics and enzymatic characterization of $\alpha$-amylase from Saccharomycopsis fibuligera KZ. Protein J. 2010, 29, 355-364. https://doi.org/10.1007/s10930-010-9260-6

[70] Tagomori B.Y., Dos Santos F.C., Barbosa-Tessmann I.P., Recombinant expression, purification, and characterization of an $\alpha$-amylase from Massilia timonae. 3 Biotech 2021, 11, 13. https://doi.org/10.1007/s13205-020-02505-w

[71] Li C., Du M., Cheng B., Wang L., Liu X., Ma C., Yang C., Xu P., Close relationship of a novel Flavobacteriaceae $\alpha$-amylase with archaeal $\alpha$-amylases and good potentials for industrial applications. Biotechnol Biofuels 2014, 7, 18. https://doi. org/10.1186/1754-6834-7-18

[72] Janecek S., Zamocka B., A new GH13 subfamily represented by the $\alpha$-amylase from the halophilic archaeon Haloarcula hispanica. Extremophiles 2020, 24, 207-217. https://doi. org/10.1007/s00792-019-01147-y

[73] van der Kaaij R.M., Janecek S., van der Maarel M.J.E.C., Dijkhuizen L., Phylogenetic and biochemical characterization of a novel cluster of intracellular fungal $\alpha$-amylase enzymes. Microbiology 2007, 153, 4003-4015. https://doi.org/10.1099/ mic.0.2007/008607-0

[74] Da Lage J.L., Binder M., Hua-Van A., Janecek S., Casane D., Gene make-up: rapid and massive intron gains after horizontal transfer of a bacterial $\alpha$-amylase gene to Basidiomycetes. BMC Evol. Biol. 2013, 13, 40. https://doi.org/10.1186/1471-2148-1340

[75] Janickova Z., Janecek S., Fungal $\alpha$-amylases from three GH13 subfamilies: their sequence-structural features and evolutionary relationships. Int. J. Biol. Macromol. 2020, 159, 763-772. https://doi.org/10.1016/j.ijbiomac.2020.05.069

[76] Janickova Z., Janecek S., In silico analysis of fungal and chloride-dependent $\alpha$-amylases within the family $\mathrm{GH} 13$ with identification of possible secondary surface-binding sites. Molecules 2021, 26, 5704. https://doi.org/10.3390/ molecules 26185704 
[77] Janecek S., Svensson B., Henrissat B., Domain evolution in the $\alpha$-amylase family. J. Mol. Evol. 1997, 45, 322-331. https://doi. org $/ 10.1007 / \mathrm{pl} 00006236$

[78] Gabrisko M., Janecek S., Looking for the ancestry of the heavy-chain subunits of heteromeric amino acid transporters rBAT and 4F2hc within the GH13 $\alpha$-amylase family. FEBS J. 2009, 276, 7265-7278. https://doi.org/10.1111/j.17424658.2009.07434.x

[79] Fort J., de la Ballina L.R., Burghardt H.E., Ferrer-Costa C., Turnay J., Ferrer-Orta C., Uson I., Zorzano A., FernandezRecio J., Orozco M., Lizarbe M.A., Fita I., Palacin M., The structure of human 4F2hc ectodomain provides a model for homodimerization and electrostatic interaction with plasma membrane. J. Biol. Chem. 2007, 282, 31444-31452. https:// doi.org/10.1074/jbc.M704524200

[80] Wu D., Grund T.N., Welsch S., Mills D.J., Michel M., Safarian S., Michel H., Structural basis for amino acid exchange by a human heteromeric amino acid transporter. Proc. Natl. Acad. Sci. USA 2020, 117, 21281-21287. https://doi.org/10.1073/ pnas. 2008111117

[81] Fairweather S.J., Shah N., Br]er S., Heteromeric solute carriers: function, structure, pathology and pharmacology. Adv. Exp. Med. Biol. 2021, 21, 13-127. https://doi. org/10.1007/5584_2020_584

[82] Fort J., Nicolas-Arago A., Palacin M., The ectodomains of rBAT and $4 \mathrm{~F} 2 \mathrm{hc}$ are fake or orphan $\alpha$-glucosidases. Molecules 2021, 26, 6231. https://doi.org/10.3390/molecules26206231

[83] Fukusumi S., Kamizono A., Horinouchi S., Beppu T., Cloning and nucleotide sequence of a heat-stable amylase gene from an anaerobic thermophile, Dictyoglomus thermophilum. Eur. J. Biochem. 1988, 174, 15-21. https://doi. org/10.1111/j.1432-1033.1988.tb14056.x

[84] Laderman K.A., Asada K., Uemori T., Mukai H., Taguchi Y., Kato I., Anfinsen C.B., $\alpha$-Amylase from the hyperthermophilic archaebacterium Pyrococcus furiosus. Cloning and sequencing of the gene and expression in Escherichia coli. J. Biol. Chem. 1993, 268, 24402-24407. https://doi.org/10.1016/S00219258(20)80539-0

[85] Janecek S., Sequence of archaeal Methanococcus jannaschii $\alpha$-amylase contains features of families 13 and 57 of glycosyl hydrolases: a trace of their common ancestor? Folia Microbiol. 1998, 43, 123-128. https://doi.org/10.1007/BF02816496

[86] Imamura H., Fushinobu S., Yamamoto M., Kumasaka T., Jeon B.S., Wakagi T., Matsuzawa H., Crystal structures of 4- $\alpha$-glucanotransferase from Thermococcus litoralis and its complex with an inhibitor. J. Biol. Chem. 2003, 278, 1937819386. https://doi.org/10.1074/jbc.M213134200

[87] Imamura H., Fushinobu S., Jeon B.S., Wakagi T., Matsuzawa $\mathrm{H}$., Identification of the catalytic residue of Thermococcus litoralis 4- $\alpha$-glucanotransferase through mechanism-based labeling. Biochemistry 2001, 40, 12400-12406. https://doi. org/10.1021/bi011017c

[88] Zona R., Chang-Pi-Hin F., O’Donohue M.J., Janecek S., Bioinformatics of the glycoside hydrolase family 57 and identification of catalytic residues in amylopullulanase from Thermococcus hydrothermalis. Eur. J. Biochem. 2004, 271, 2863-2872. https://doi.org/10.1111/j.14321033.2004.04144.x

[89] Palomo M., Pijning T., Booiman T., Dobruchowska J.M., van der Vlist J., Kralj S., Planas A., Loos K., Kamerling J.P., Dijkstra
B.W., van der Maarel M.J., Dijkhuizen L., Leemhuis H., Thermus thermophilus glycoside hydrolase family 57 branching enzyme: crystal structure, mechanism of action, and products formed. J. Biol. Chem. 2011, 286, 3520-3530. https://doi. org/10.1074/jbc.M110.179515

[90] Blesak K., Janecek S., Sequence fingerprints of enzyme specificities from the glycoside hydrolase family $\mathrm{GH} 57$. Extremophiles 2012, 16, 497-506. https://doi.org/10.1007/ s00792-012-0449-9

[91] Blesak K., Janecek S., Two potentially novel amylolytic enzyme specificities in the prokaryotic glycoside hydrolase $\alpha$-amylase family GH57. Microbiology 2013, 159, 2584-2593. https://doi. org/10.1099/mic.0.071084-0

[92] Martinovicova M., Janecek S., In silico analysis of the $\alpha$-amylase family GH57: eventual subfamilies reflecting enzyme specificities. 3 Biotech 2018, 8, 307. https://doi. org/10.1007/s13205-018-1325-9

[93] Laderman K.A., Davis B.R., Krutzsch H.C., Lewis M.S., Griko Y.V., Privalov P.L., Anfinsen C.B., The purification and characterization of an extremely thermostable $\alpha$-amylase from the hyperthermophilic archaebacterium Pyrococcus furiosus. J. Biol. Chem. 1993, 268, 24394-24401. https://doi. org/10.1016/S0021-9258(20)80538-9

[94] Nakajima M., Imamura H., Shoun H., Horinouchi S., Wakagi T., Transglycosylation activity of Dictyoglomus thermophilum amylase A. Biosci. Biotechnol. Biochem. 2004, 68, 23692373. https://doi.org/10.1271/bbb.68.2369

[95] Kim J.W., Flowers L.O., Whiteley M., Peeples T.L., Biochemical confirmation and characterization of the family-57-like $\alpha$-amylase of Methanococcus jannaschii. Folia Microbiol. 2001, 46, 467-473. https://doi.org/10.1007/BF02817988

[96] Ballschmiter M., Fütterer O., Liebl W., Identification and characterization of a novel intracellular alkaline $\alpha$-amylase from the hyperthermophilic bacterium Thermotoga maritima MSB8. Appl. Environ. Microbiol. 2006, 72, 2206-2211. https:// doi.org/10.1128/AEM.72.3.2206-2211.2006

[97] Dickmanns A., Ballschmiter M., Liebl W., Ficner R., Structure of the novel $\alpha$-amylase AmyC from Thermotoga maritima. Acta Crystallogr. D Biol. Crystallogr. 2006, 62, 262-270. https:// doi.org/10.1107/S090744490504136

[98] Zhang X., Leemhuis H., Janecek S., Martinovicova M., Pijning T., van der Maarel M.J.E.C., Identification of Thermotoga maritima MSB8 GH57 $\alpha$-amylase AmyC as a glycogenbranching enzyme with high hydrolytic activity. Appl. Microbiol. Biotechnol. 2019, 103, 6141-6151. https://doi. org/10.1007/s00253-019-09938-1

[99] Xiang G., Leemhuis H., van der Maarel M.J.E.C., Structural elements determining the transglycosylating activity of glycoside hydrolase family 57 glycogen branching enzymes. Proteins 2021, in press. https://doi.org/10.1002/prot.26200

[100] Li X., Li D., Park K.H., An extremely thermostable amylopullulanase from Staphylothermus marinus displays both pullulan- and cyclodextrin-degrading activities. Appl. Microbiol. Biotechnol. 2013, 97, 5359-5369. https://doi. org/10.1007/s00253-012-4397-1

[101] Janecek S., Blesak K., Sequence-structural features and evolutionary relationships of family $\mathrm{GH} 57 \alpha$-amylases and their putative $\alpha$-amylase-like homologues. Protein J. 2011, 30, 429-435. https://doi.org/10.1007/s10930-011-9348-7 
[102] Janecek S., Martinovicova M., New groups of protein homologues in the $\alpha$-amylase family GH57 closely related to $\alpha$-glucan branching enzymes and 4- $\alpha$-glucanotransferases. Genetica 2020, 148, 77-86. https://doi.org/10.1007/s10709020-00089-0

[103] Watanabe H., Nishimoto T., Kubota M., Chaen H., Fukuda S., Cloning, sequencing, and expression of the genes encoding an isocyclomaltooligosaccharide glucanotransferase and an $\alpha$-amylase from a Bacillus circulans strain. Biosci. Biotechnol. Biochem. 2006, 70, 2690-2702. https://doi.org/10.1271/ bbb.60294

[104] Valk V., van der Kaaij R.M., Dijkhuizen L., The evolutionary origin and possible functional roles of FNIII domains in two Microbacterium aurum B8.A granular starch degrading enzymes, and in other carbohydrate acting enzymes. Amylase 2017, 1, 1-11. https://doi.org/10.1515/amylase-2017-0001

[105] Nakada T., Maruta K., Mitsuzumi H., Kubota M., Chaen H., Sugimoto T., Kurimoto M., Tsujisaka Y., Purification and characterization of a novel enzyme, maltooligosyl trehalose trehalohydrolase, from Arthrobacter sp. Q36. Biosci. Biotechnol. Biochem. 1995, 59, 2215-2218. https://doi. org/10.1271/bbb.59.2215

[106] Janecek S., Kuchtova A., In silico identification of catalytic residues and domain fold of the family GH119 sharing the catalytic machinery with the $\alpha$-amylase family GH57. FEBS Lett. 2012, 586, 3360-3366. https://doi.org/10.1016/j. febslet.2012.07.020

[107] Ficko-Blean E., Stuart C.P., Boraston A.B., Structural analysis of CPF_2247, a novel $\alpha$-amylase from Clostridium perfringens. Proteins 2011, 79, 2771-2777. https://doi.org/10.1002/ prot.23116

[108] Aleshin A., Golubev A., Firsov L.M., Honzatko R.B., Crystal structure of glucoamylase from Aspergillus awamori var. X100 to 2.2-Å resolution. J. Biol. Chem. 1992, 267, 19291-19298. https://doi.org/10.1016/S0021-9258(18)41773-5

[109] Aleshin A.E., Feng P.H., Honzatko R.B., Reilly P.J., Crystal structure and evolution of a prokaryotic glucoamylase. J. Mol. Biol. 2003, 327, 61-73. https://doi.org/10.1016/s00222836(03)00084-6

[110] Sauer J., Sigurskjold B.W., Christensen U., Frandsen T.P., Mirgorodskaya E., Harrison M., Roepstorff P., Svensson B., Glucoamylase: structure/function relationships, and protein engineering. Biochim. Biophys. Acta 2000, 1543, 275-293. https://doi.org/10.1016/s0167-4838(00)00232-6

[111] Guerin D.M., Lascombe M.B., Costabel M., Souchon H., Lamzin V., Beguin P., Alzari P.M., Atomic (0.94 ̊̊) resolution structure of an inverting glycosidase in complex with substrate. J. Mol. Biol. 2002, 316, 1061-1069. https://doi.org/10.1006/ jmbi.2001.5404

[112] Guimaraes B.G., Souchon H., Lytle B.L., David Wu J.H., Alzari P.M., The crystal structure and catalytic mechanism of cellobiohydrolase CelS, the major enzymatic component of the Clostridium thermocellum cellulosome. J. Mol. Biol. 2002, 320, 587-596. https://doi.org/10.1016/s0022-2836(02)00497-7

[113] Wu H., Qiao S., Li D., Guo L., Zhu M., Ma L.Z., Crystal structure of the glycoside hydrolase PssZ from Listeria monocytogenes. Acta Crystallogr. F Struct. Biol. Commun. 2019, 75, 501-506. https://doi.org/10.1107/S2053230X19008100
[114] Köseoglu V.K., Heiss C., Azadi P., Topchiy E., Güvener Z.T., Lehmann T.E., Miller K.W., Gomelsky M., Listeria monocytogenes exopolysaccharide: origin, structure, biosynthetic machinery and c-di-GMP-dependent regulation. Mol. Microbiol. 2015, 96, 728-743. https://doi.org/10.1111/ mmi.12966

[115] Kerenyiova L., Janecek S., A detailed in silico analysis of the amylolytic family GH126 and its possible relatedness to family GH76. Carbohydr Res. 2020, 494, 108082. https://doi. org/10.1016/j.carres.2020.108082

[116] Kerenyiova L., Janecek S., Extension of the taxonomic coverage of the family GH126 outside Firmicutes and in silico characterization of its non-catalytic terminal domains. 3 Biotech 2020, 10, 420. https://doi.org/10.1007/s13205-02002415-x

[117] Thompson A.J., Speciale G., Iglesias-Fernandez J., Hakki Z., Belz T., Cartmell A., Spears R.J., Chandler E., Temple M.J., Stepper J., Gilbert H.J., Rovira C., Williams S.J., Davies G.J., Evidence for a boat conformation at the transition state of GH76 $\alpha$-1,6-mannanases - key enzymes in bacterial and fungal mannoprotein metabolism. Angew. Chem. Int. Ed. Engl. 2015, 54, 5378-5382. https://doi.org/10.1002/anie.201410502 